\title{
EPONYMIC PLACE NAMES IN ZAMBIA: \\ A CRITICAL TOPONYMIES PERSPECTIVE
}

\author{
Cheela Chilala \\ University of Zambia \\ c.chilala@unza.zm \\ Khama Hang'ombe \\ University of Zimbabwe \\ hangombek@yahoo.com
}

\begin{abstract}
This study examines eponymic place names in Zambia, specifically focusing on names of international airports and national stadia. Names of these features have been selected for study because in 2011, they had been subjected to changes. The study brings out the doubled nature of this name change by the Patriotic Front regime: to commemorate Zambia's heroes and to entrench their political stamina. To successfully bring out the double edged nature of place name change by the Patriotic Front regime, the study engages Critical Toponymies Theory, a theory which considers place names as social artefacts which are caught up in a web of social conflict, implicating them as key players in (re)producing unequal socio-political power balance, an aspect which can be viewed as a social problem. The study argues that names of key national places or features in Zambia, banal and mundane as they may appear, are implicated in formulating and perpetuating social classes and power imbalance in the country because they are agents that promote the ideologies, aspirations and worldview of the ruling elites.
\end{abstract}

Keywords: Eponymic Place Names, Critical Toponymies Theory, Zambia, Social Conflict and Power Imbalance

\section{Introduction}

This study is on the political dimension of place names. The study specifically examines names of key national places and features in Zambia, seeking to expose how names of such places were utilised by the Patriotic Front government to enhance their political niche in Zambia. Many studies on place names have argued for the importance of place names as historical records, identity markers (cf Chabata, 2007; Rajić, 2012) and descriptors of the geographical locale they name (cf Chabata, 2012; Donada and Reinoso, 2015), a view which warrants a conception of them as being innocent socio-politically. However, there are many place names studies that have demonstrated that no matter how mundane place 
names may appear, they are involved in the (re)production of unequal power balance in societies (cf Light and Young, 2014; Post and Alderman, 2014; Rose-Redwood and Alderman, 2011).

The data used for this study are names of international airports and national stadia in Zambia. The choice of names for these places/features is driven by the fact that the Patriotic Front government under the leadership of Micheal Chilufya Sata the fifth president of Zambia changed the names of these places/features in 2011. The change of names of key national places/features has been done by Sata's presidency while in the previous governments this was not done. It appears that president Sata and his government had an onomastic agenda or at least, was very mindful of the power of place names. Since place names are important for advancement of agenda and establishing social identities (Perko, Jordan, and Komac, 2017), an examination of such names is likely to expose Sata's government's interests and agenda in changing the names of these places/features.

As may be deduced, most of place names that the study examines form part of urban toponymic landscape, with a higher chance of most of them being located in big cities in the country. Studies elsewhere (cf Light and Young, 2014; Rose-Redwood and Alderman, 2011) indicate that governments and politicians tend to manipulate names that form part of the urban toponymic landscape more names than those that form part of the rural toponymic landscape.

The study uses Critical Toponymies Theory in the analysis of the names. Using this theory, the study reveals that, in addition to being historical records, identity markers and geographical descriptors, place names are social artefacts that are used in agenda advancement. This study draws inspiration from Madden (2017); Light (2014); Medway and Warnaby (2014) who espouse a critical toponymic perspective in dismissing the seemingly innocent nature of place names. The underlying argument in Critical Toponymies Theory is that place names are biased intangible heritages in the sense that the history they record, worldview, culture and identity they depict, are all from the perspective of their bestowers. This view of place names suggests that place naming itself is a contested process because different groups of people may yearn to inscribe their identity, ideologies, history, culture and worldview in their environment by naming their places. Accentuating the contest that characterises place naming, Perko, Jordan and Komac (2017:103) opine that, individually or collectively, people are never in equal positions to name places. It is this contest, which draws place names in a web of social power imbalance.

The study notes that names of key places/features in Zambia are predominantly eponymous. That is to say they are named after individuals, some still alive while others deceased, who played a role in the independence struggle or in the governance of the country. As such, most of the people the places/features are named after have or had a high status or influential position in the country.

An argument is made in the study that the names of key national features are not apolitical, although they appear so at face value. These names are emblems of the power of those whose agenda and interest they mirror; the bestowers. As such, the names help in advancing the political agenda of the bestowers. These names, therefore, can be implicated in political power struggles in the country. They are power arsenals used by the ruling elites to fortify their political determination while their counterparts who may also aspire to be in national leadership positions have no privilege to use the naming of the same 
places/features in their quest to win political leverage in the country. Thus, the names are capable of formulating and perpetuating unequal political power balance on the political frontage in the country.

At the heart of the naming of spaces or infrastructure is the question of who has or should have the power to name, what Chilala in 'The Adamic Licence in Ellen BandaAaku's Patchwork' (2016) calls the Adamic Licence, drawn from biblical Adam's divinelygiven authority to name the animals in the Garden of Eden. The Adamic Licence, as Chilala states, 'is not confined to the naming of living things such as dogs, cows, horses, birds or human beings, but also the naming of non-living things within the literary works such as places and objects' (156-7). Although in the work quoted above Chilala focuses on the use of the Adamic Licence in the context of literary texts, it may also be argued that the Adamic Licence is also applicable in non-literary contexts. Thus, with regard to question of eponymous place names and infrastructure in Zambia, it might be argued that the question of who should do the naming, as will be demonstrated in this article, is a contested space.

\section{The Republic of Zambia: A Brief Political Historical Background}

The Republic of Zambia, located in southern Africa, is a former British protectorate. Zambia attained her independence from British rule in 1964 after a protracted struggle in which some patriotic Zambians lost their lives. At independence, the United National Independence Party (UNIP) formed government with Kenneth Kaunda, its leader, becoming the first republican president.

Some of the prominent figures who were active in the fight for independence, most of whom were part of the team which occupied government positions on the UNIP party when the country became independent, were Harry Mwaanga Nkumbula and Mainza Chona both from Southern Province, Mbikusita Lewanika from Western Province and Simon Mwansa Kapwepwe (who was vice president of Zambia from 1967-1979) from Muchinga Province.

In 1991, the Movement for Multi-party Democracy (MMD) ousted UNIP through the ballot. Its leader, Fredrick Chiluba became the second republican president up to 2002. In the 2002 presidential election, Chiluba did not contest because he was not eligible according to the constitution. The MMD fielded Levy Patrick Mwanawasa, who won the election, becoming the third republican president. Mwanawasa ruled Zambia from 2002 to 2008 when he passed away as a sitting president. Mwanawasa was succeeded by Rupiah Banda who ruled Zambia from 2008 to 2011. In 2011, Zambia held presidential and general elections and Michael Chilufya Sata of the Patriotic Front (PF) was voted president and ruled Zambia from 2011 to 2014 when he also passed away as a sitting president. Edgar Chagwa Lungu succeeded Sata and became president of Zambia under the PF party from 2014 to date.

An observation can be made that of all the regimes that Zambia has had, it is only in President Sata's regime that names of key national places have been changed. It is also during this regime that a heated debate or objection over a name that was given to a stadium occurred. This suggests that president Sata sought to tap into the power that is inherent in a place name in his quest to buttress his political weight in Zambia. 


\section{Critical Toponymies Theory}

Critical Toponymies Theory (CTT), a theory which re-politicises place names, was popularised in the 1990s. Some of the advocates of CTT are Myers (2009); Rose-Redwood and Alderman (2011); Rose-Redwood,Alderman and Azaryahu (2010). The main argument in this theory is that place names are not neutral social artefacts. Rather, they can be used in harnessing the aspirations of the namers in the toponymic landscape. This makes place naming a contested social practice. Since people do not have the same privileges as far as place names bestowal is concerned (Perko, Jordan and Komac, 2017:103), those who are powerful politically or socially win the contest to nominate places. It follows then, that the names bestowed on places reflect their agenda, aspirations, version of the history and conception of the world.

Among other aspects, place names can have an economic nuance (Light, 2014). In such an instance, place names may be attuned to the economical agenda of the bestower. Place names can also have a political penchant (Melissa and Kosuke, 2016), whereby the names are inclined toward the political aspirations of the bestower which is referred to as political semiotics. In political semiotics, the names assigned to places may be those which celebrate or commemorate politicians or at least, reflect the ideologies of the government. Scalar is yet another aspect reflected in place names (cf Hagen, 2011). Scalar can have to do with the selection of a place name guided by whether the place is of (inter)national significance or not. If a place is of (inter)national significance, for example, the place can be bestowed a name which also attracts (inter)national visibility.

In this study, CTT is used in the analysis of the names to expose that the names of key national features in Zambia have some political semiotics. The analysis touches on place name change is also touched upon as it reflects on and provides rich insights into the politics of place naming and social power dynamics. The aspect of resistance that Sata's government encountered in bestowing some of the names to features is also touched upon to in this study.

In essence, there is no such thing as an innocent name, and even the presumption of 'neutral' names is a contested space. In onomastic studies, the famous Shakespearian question has been asked: What's in a name? Names and naming matter. It is not just the type of name given that matters, but also the circumstances in which it is given (Chilala, 2019). In this regard, CTT is a useful tool in interrogating the why, when and how of name-giving.

\section{Data Presentation and Discussion}

This section presents and discusses the names of international airports and national stadia. Critical Toponymies Theory provides the lenses through which the names and name changes are viewed.

\section{International Airports}

Zambia has three main international airports: Kenneth Kaunda International Airport, Harry Mwaanga Nkumbula International Airport and Simon Mwansa Kapwepwe International 
Airport. Mfuwe Airport, located in South Luangwa National Park, is also an international airport but only takes international flights in the tourism sector. For this reason, Mfuwe is not included in the analysis in this study.

\section{Kenneth Kaunda International Airport}

Kenneth Kaunda International Airport (KKIA) is found in Lusaka, the capital city of Zambia. The airport was established in 1967. Formerly, it was known as Lusaka International Airport. The airport was renamed after Kenneth Kaunda, Zambia's first republican president, during Sata's presidency in 2011.

\section{Simon Mwansa Kapwepwe International Airport}

Simon Mwansa Kapwepwe is located in Ndola in the Copperbelt Province of Zambia. This airport was established in 1938 as a military base for the Royal Air Force of England during the colonial period and was meant to service British troops during the Second World War as they fought the German army. It was only changed into a civilian airport in the 1950s. Until 2011, when it was renamed in honour of Simon Mwansa Kapwepwe, this airport was known as Ndola International Airport. Simon Mwansa Kapwepwe was a vice-president of Zambia from 1967 to 1970.

Ndola is one of the key towns in Zambia. In addition to being the commercial and industrial centre of the Copperbelt Province of Zambia, it is also the commercial capital city of Zambia. Ndola is the third largest city in Zambia with a population of 451,246 (https://en.wikipedia.org/wiki/List_of_cities_and_towns_in_Zambia). This implies that Ndola, just like Lusaka, is a very important city in Zambia.

\section{Harry Mwaanga International Airport}

Harry Mwaanga Nkumbula International Airport is located in Livingstone in the Southern Province of Zambia. This airport was established in 1950. Previously, the airport was called Livingstone International Airport. It was renamed Harry Mwaanga Nkumbula International Airport in 2011, in honour of Harry Mwaanga Nkumbula, a politician who was involved in the liberation struggle for Zambia. Nkumbula was the leader of the Zambian African National Congress Party, a party which later formed a coalition with the United National Independence Party. Livingstone is a very important town in Zambia because it is a tourist capital.

The names of the three international airports in Zambia exhibit political semiotics. They are named after politicians, who took part in the liberation struggle. As already seen, the renaming of the airports was done in 2011 under the administration of the late President Sata. Before then, the national airports were named after the towns in which they are located and no attempts had been made at renaming the airports by either the previous or the successive governments.

It appears that the PF government, under Sata, had realised that there was something in the name: the power not only to honour and celebrate past heroes, but also to help in strengthening political vitality by winning the hearts of the electorate. They used naming as a tool to celebrate Zambia's heroes. There are other Zambian politicians that President 
Sata promised would be honoured by having universities named after them. For example, when he visited Western Province of Zambia in 2013, he promised the people of Mongu that government would build them a university and name it King Lewanika University. Lewanika was the name of the Lozi leader who ruled from 1878 to 1916 . To contextualise the importance of the promise to build a university in Mongu and name it after the Lozi king, one needs to understand that the Lozi people have been putting pressure on the government of Zambia to allow Barotseland to rule itself or to honour the Barotseland Agreement of 1964.

Since the politicians whom the stadia were named after were respected and adored by the majority of Zambians, the PF may have been aware that such a nomenclature would make them popular among the Zambians. Thus, an argument that there was a hidden agenda by the PF in renaming the airports after Zambia's heroes can be made. The agenda could be that they hoped to woo the support of the people who adored the three leaders. Renaming the Lusaka International Airport to Kenneth Kaunda International Airport, for example, would appeal to members of the former ruling party, UNIP, whose existence and rule were epitomised by Kaunda. Similarly, evoking the names of Kapwepwe and Nkumbula would endear the PF government in the eyes of voters in Muchinga and Southern provinces respectively. Related to this argument is Bassin (2000a:250) and Gill (2005:480)'s assertion that political regimes manipulate the toponymic landscape in order to affirm their control of territory and promote their ideological norms.

It seems that the PF were also aware of the best location of the places that could aptly execute their aspirations. They targeted airports located in key cities and these are international airports. They did not seek to rename airports in other towns which to date still have the names of the towns where they are found. Such a mondus operandi in place naming is echoed by Light (2014) who argues that governments tend to have more interest in urban toponymic landscapes than in the rural one.

President Lungu, the current president of Zambia seems to have continued the onomastic vision that his predecessor had. Lungu has named the university under construction in Luapula Province of Zambia after the second republican president, Chiluba. Luapula Province is believed to be the homeland for Chiluba. It would make sense to think that naming a university in Luapula Province after late President Chiluba who hailed from this province was a strategy to impress the people in the province. This would, in turn, increase chances for the PF regime to garner more votes from the province during elections. However, this study is specifically on names of international airports and stadia in the country because these have a national and sometimes international visibility.

From Critical Toponymies Theory perspective, using scalar toponymy theme, firstly, the PF government concentrated on the top scale airports in Zambia because they command more visibility than others. To these airports, they assigned names that command respect and adoration nationally and internationally in some cases. Secondly, the PF considered scale in terms of the location of the airports. Thus, they inscribed their nationalistic agenda on the airports located in critical cities in the country: Lusaka-the national capital city, Livingstone- Zambia's tourism capital, and Ndola- the commercial capital city of Zambia. 
It might be worth discussing, at this point, especially from the perspective of contestation of place-naming, that some people argued that Lusaka International Airport should not have been renamed because keeping the Lusaka name honoured the Soli headman, Lusaaka, after whom the city was named. From the perspective of CTT, then, it might be opined that the political leaders ultimately had their way because they are the ones with the authority and privilege to (re)name places. A similar argument might be used by the Lamba people who also have their own heroes after whom they would want the airport named. Kapwepwe, it ought to be noted, was not from Lambaland. Similarly, Nkumbula, apart from the fact that he hailed from Southern Province where Livingstone is located, did not hail from among the Toka-Leya, who are indigenous to the Livingstone area.

\section{Names of International Stadia}

There are two international stadia in Zambia: Heroes National Stadium in Lusaka and Levy Mwanawasa Stadium in Ndola. Both stadia are owned by the Zambian Government.

\section{Heroes National Stadium}

The National Heroes Stadium is located in Lusaka. The stadium was constructed in 2013 during Sata's presidency. It is a multi-purpose stadium with a 60,000 sitting capacity. The stadium often hosts international football matches, presidential inauguration ceremonies and funerals of key national figures such as presidents. For example, the funeral ceremony of late Michael Chilufya Sata, the $5^{\text {th }}$ President of the Republic of Zambia, was held in this stadium on 11 November, 2014. Initially, this stadium was named Gabon Disaster Heroes National Stadium, after the Zambian National Football Team that died in an air crush in the Atlantic Ocean off the coast of Gabon en route to Senegal for a World Cup qualifier match in 1993. This name was rejected by most Zambians, forcing government to change it to National Heroes Stadium, still in honour of the football team.

In expressing objection to the name Gabon Disaster Heroes National Stadium, one blogger had this to say:

Old Trafford, Camp Nou, San Siro, Maracana, Royal Bafokeng, Allianz Arena, Nkoloma, then some 'genius' just had to go and put Gabon Disaster Heroes National Stadium to this glorious list of stadium names. I am still dumbfounded at how the new ultramodern stadium can be bestowed such a name. The naming of this stadium is a perfect example why God gave us different talents, the creativity of naming places was not given to the person who was responsible for naming this stadium. Honestly, of all the names that are out there why pick on this one, WHY? (Available online at: https:// diaryofafrustratedbrotha.blogspot.com/2013/07/gabon-disaster-heroesnational-stadium_10.html).

This blogger seems to suggest that the word 'disaster' in the name has a negative connotation which filters through the name Gabon Disaster Heroes National Stadium. The other dissatisfaction about the name Gabon Disaster Heroes National Stadium can be seen from an online newspaper (Lusaka Times) report on 11 July, 2013: 
Cabinet has finally approved the name of Lusaka stadium, which will be called Gabon Disaster Heroes National Stadium... [However] a lot of Zambians have expressed shock and disappointment at the name. The two soccer Associations namely; the Zambia Soccer Fans Association and the Zambia Sports Fans Association are not happy that government has included 'Gabon' and 'Disaster' to the new name... Kalusha [Bwalya] yesterday tweeted that 'Heroes Stadium' is more appropriate as it will include the heroic performances by national teams of 1974, 1993, 1994 and that for 2012 which won the Africa Cup... Soccer fans talked to said they could not believe national leaders could come up with such a name (Available online at: https://www.lusakatimes.com/2013/07/11/gabon-disaster-heroesnational-stadium/).

It is clear from the report that the objection to the name was triggered by the inclusion of the word 'disaster' in the name. This case demonstrates that a good name is that which has positive associations. Commenting on how people select place names, Algeo (1999) observes that namers seem to be aware that a good name must be memorable, distinctive and should be positive in association. In the case of the name Gabon Disaster Heroes National Stadium, the quality of 'positive in association' was missing, hence, most Zambians rejected it. A rejection of place names is also reported by Mbenzi (2009) where a heated debate in the Namibian parliament ensued from a proposal to rename places in Namibia in 2005. The main reason for the objection, however, was lack of agreement on which language the places were to be renamed.

In Zambia, playing for the national soccer team is highly prestigious and fairly well-paying. As a result, soccer players in the team are famous and celebrated by most Zambians, especially soccer fans. This is the reason why the Zambian Government during Sata's presidency decided to honour the 1993 Gabon aircraft disaster victims by naming it for them. Possibly, the PF government's ulterior motive was to win the love and trust of Zambians by identifying themselves with what they cherished the most. A win of the love and trust of the Zambian masses would then translate into more votes during elections.

\section{Levy Mwanawasa Stadium}

Levy Mwanawasa Stadium is a multi-purpose stadium located in Ndola in the Copperbelt Province of Zambia. The stadium was built in 2011 with a sitting capacity of 49,800 . It is used mostly for international football matches. The first football match played in this stadium, a World Cup qualifier match, was in 2012 between Zambia and Ghana and the result was 1-0 in favour of Zambia. The importance of the town in which this stadium is found has already been discussed.

This stadium was named after President Levy Patrick Mwanawasa who was the Third Republican President of Zambia. President Mwanawasa is remembered both locally and internationally for his strong fight against corruption and good economic policies (Orbituary, 2008). Put plainly, Mwanawasa left a very good legacy as far as the fight against corruption in Zambia and improving the economy of Zambia was concerned. Thus, 
naming a place after him accords the place an excellent brand name. Another argument used in support of honouring Mwanawasa was that he, was in fact, the originator of the efforts that lobbied the Chinese Government to build the stadium.

The names given to the two stadia can be said to be names associated with prestige and high status. As earlier argued, with regard to the names of the airports in this study, the PF government may have had another agenda other than merely using the names to celebrate the eponyms. Since the eponyms were loved by most of the people in the country, and recognised internationally, the PF may have deliberately chosen to name the stadia after them so as to win the support of most Zambians, a state of affairs which would fortify their efforts to remain in power for a longer period of time.

\section{Conclusion}

The study noted that names of most of the key national places/features in Zambia are eponymous. The selection of these eponymous names seems to be done systematically by the namers, with a socio-political agenda driving the selection. Before focussing on the agenda, it is necessary to comment on the aspect of renaming as seen with most of the places discussed in this article.

Zambia has so far gone through five regime changes. By regime change, we simply mean different presidents. We are aware that some of the presidents, for example, President Chiluba (1991 to 2002) and Mwanawasa (2002 to 2008), were both from the MMD party. Of all the five regime changes, so far, it is in President Sata's regime where noticeable name change of key places occurred.

The study has demonstrated that the (re)naming of key places in 2011 had a sociopolitical predilection. The (re)naming produced place names that recognised and commemorated the eponyms. On the other hand, the (re)naming produced names which gave the PF government political leverage. This would, as probably was their hope, enable the PF government to stay longer in power. Thus, the study pins down names of key national places or features as key players in (re)producing and embedding the power of those that have power, political power in this case. The (re)naming of places for political expedience has also been reported by Ndletyana (2012) in South Africa and by Mbenzi (2009) in Namibia at independence.

Anchored on the data from the study, a conclusion can be made that when PF government sought to fortify its political stamina, it turned to the names of national interest and significance and manipulated them. The manipulation was done by (re)naming the places in a way that produced names which would invoke and excite the love of most Zambians toward the PF government. This conclusion is germane to Rose-Redwood and Alderman (2011)'s observation that governments tend to have more interest in names of important places in urban toponymic landscapes than with the rural landscape. As can be seen in the data from the study, most of the bestowed on key national features are names of influential individuals some outstanding internationally, and most of them politicians. Thus, they are individuals with high status. This makes the places named for them prestigious. 
It is also worth noting that the naming of these significant spaces, at least, in terms of the stadia and airports discussed, appears to be tilted towards honouring men - as if there are no significant women achievers in the history of Zambia. Although the airports are named after patriarchs of the freedom struggle: Kenneth Kaunda, Harry Mwaanga Nkumbula, and Simon Mwansa Kapwepwe, there are many women who contributed to the struggle for independence such as Mama Julia Chikamoneka and even the wives of the three freedom fighters. This apparent marginalisation of women freedom fighters in the naming space is reflective of the marginalisation of women when considering heroes even in other areas of human endeavour in Zambia. For example, as Chilala argues, women's exploits are not easily acknowledged (such as Nora in A Doll's House - Chilala, 2003), and male writers tend to gravitate towards picking male characters as heroes of their stories rather than female ones (Chilala, 2006; Chilala, 2013). In interrogating the use of Adamic Licence in the naming of the airports, it ought to be noted that the choice of names came in the context of renaming the airports. It would have been possible, in changing the names, to also consider women freedom fighters. The fact that no woman freedom fighter has an airport named after her suggests the absence of a clear naming or onomastic policy on the part of the government, just as there appears to be no clear policy on naming of streets in Lusaka (Wakumelo et al., 2016).

In the case of the two stadia discussed in the study, gender bias, it might be argued, is still a factor, although perhaps not as pronounced as in the case of the renamed airports. The Levy Mwanawasa Stadium was initially called Ndola Stadium, but changed to Levy Mwanawasa by the PF. While the stadium in Lusaka is called National Heroes Stadium, it might be helpful to ask the question: which heroes? It is apparent from this study that the initial onomastic intent was to honour the Zambia National Football Team players who perished in the airplane crash in Gabon. The footballers were male, as were the coaching staff. The name of the stadium, therefore, cannot be divorced from the gender-biased conceptions of heroism in Zambia.

\section{References}

Algeo, J. (1999). 'Trans-Atlantic Street Names.' Names, 47(3): 205-214.

Bassin, M. (2000a). Landscape and Identity in Russian and Soviet Art: An Introduction Ecumene, 7:249-51.

Chabata, E. (2007).'The Role of Place Names in the Making of a Zimbabwean Identity.' Nytt om Namm 46:13-17.

Chabata, E. (2012). 'Feature Names and Identity in Zimbabwe.' Oslo Studies in Language 4(2):30-45.

Chilala, C.F.K. (2003). 'Marriage, Gender and Freedom in Henrik Ibsen's A Doll's House: A Zambian Perspective.' Proceedings of The Relevance of A Doll's House - Translation and Adaptation, International Ibsen Conference, Dhaka, Bangladesh, 8-14 November 2002: 101-118.

Chilala, C. (2006). An Analysis of Gender Issues in Zambian Literature in English. Master's Thesis. The University of Zambia. 
Chilala, C. (2013). 'Through the Male Eyes: Gendered Styles in Contemporary Zambian Fiction.' Reading Contemporary African Literature: Critical Perspectives: 91-99.

Chilala, C.H. (2016). 'The Adamic Licence in Ellen Banda-Aaku's Patchwork.' The Postcolonial Condition of Names and Naming Practices in Southern Africa: 155-171.

Chilala, C. (2019). 'Gendered Spaces in Chinua Achebe's Things Fall Apart: Text, Context and Pretext.' Theoretical and Applied Aspects of African Languages and Culture: $317-$ 339.

Donada, T. J., and Reinoso, S. A. (2015). Toponyms as 'Landscape Indicators.' Onomàstica: 1987-2016.

Gill, G. (2005). 'Changing Symbols: The Renovation of Moscow Place Names.' The Russian Review, 64:480-503.

Hagen, J. (2011). 'Theorizing Scale in Critical Place-name Studies.' ACME: An International E-Journal for Critical Geographies, 10(1), 23-27.

Light, D. (2014). 'Tourism and Toponymy: Commodifying and Consuming Place Names.' An International Journal of Tourism Space, Place and Environment, 16(1):141-156.

Light, D., and Young, C. (2014). 'Toponymy as Commodities: Exploring the Economic Dimensions of Urban Place Names.' International Journal of Urban and Regional Research, doi:10.1111/1468-2427.12153: 435-450.

Madden, J.D. (2017). Pushed off the Map: Toponymy and the Politics of Place in New York City. Urban Studies. ISSN 0042-098.

Mbenzi, A.P. (2009). The Management of Place Names in the Post-Colonial Period in Namibia. UNGEGN, Working Paper No. 67: Twenty-fifth Session Nairobi, 5-12 May. Medway, D., and Warnaby, G. (2014). 'What's in a Name? Place Branding and Toponymic Commodification.' Environment and Planning A, 46:153-167.

Myers, A.G. (2009). Naming and Placing the Other: Power and the Urban Landscape in Zanzibar, in Berg, D.L., and Vuolteenaho, J. (eds), Critical Toponymies: The Contested Politics of Place Naming. England: Ashgate Publishing Company: 85-100.

Ndletyana, M. (2012). 'Changing Place Names in Post-apartheid South Africa: Accounting for the Unevenness, Social Dynamics,' A Journal of African Studies, 38(1): 87-103.

Perko, D., Jordan, P., and Komac, B. 2017. Exonyms and other Geographical Names. Acta Geographica Slovenica, 57(1):99-107.

Post, W.C., and Alderman. (2014). 'Wiping New Berlin off the Map': Political Economy and the De-Germanisation of the Toponymic Landscape in First World War USA. Area, 2014, 46.1, 83-91, doi: 10.1111/area.12075.

Rajic, L. (2012). 'Toponyms and the Political and Ethnic Identity in Serbia.' Studies in Language 4(2): 185-204.

Rose-Redwood, R., and Alderman, D. (2011). 'Critical Interventions in Political Toponymy.' An International E-Journal for Critical Geographies, 2011, 10 (1):1-6.

Rose-Redwood, R., Alderman, D., and Azaryahu, M. (2010). Geographies of Toponymic Inscription: New Directions in Critical Place-name Studies. Progress in Human Geography, 34(4):453-470. 
Wakumelo, M., Mwanza, D., and Mkandawire, B. (2016). 'The Toponymics of Postcolonial Zambia: Street Naming Patterns in Lusaka.' The Postcolonial Condition of Names and Naming Practices in Southern Africa: 270-287.

\section{Internet Sources}

“Obituary: Zambia's Levy Mwanawasa”. BB C News. 19 August 2008.

https://diaryofafrustratedbrotha.blogspot.com/2013/07/gabon-disaster-heroes-nationalstadium_10.html.

https://www.lusakatimes.com/2013/07/11/gabon-disaster-heroes-national-stadium/. 